\title{
Bacteriocin production of the probiotic Lactobacillus acidophilus KS400
}

\author{
C. Gaspar1,2, G. G. Donders³,4, R. Palmeira-de-Oliveira 1,2, J. A. Queiroz² , C. Tomaz², J. Martinez-de-Oliveira 2,5 \\ and A. Palmeira-de-Oliveira ${ }^{1,2^{*}}$
}

\begin{abstract}
In the last years, the use of probiotics, including Lactobacillus species, has received much attention to prevent and treat vaginal disorders. These species have been described as having the ability to colonize the epithelial surface and produce antimicrobial metabolites that are able to control the remaining vaginal microflora. This study aimed to identify and characterize, for the first time, a bacteriocin natively produced by Lactobacillus acidophilus KS400 (probiotic strain from Gynoflor ${ }^{\circledR}$-Medinova AG, Switzerland) and its antimicrobial activity against relevant urogenital pathogens. After organic acids and hydrogen peroxide neutralization in the fermented Lactobacillus acidophilus KS400 culture medium, bacteriocin activity was tested against the indicator microorganism Lactobacillus delbrueckii ATCC9649. The fermentation of Lactobacillus acidophilus KS400 for bacteriocin production was carried out in batch mode, and its antimicrobial activity, optical density and pH were monitored. After production and extraction, the bacteriocin molecular weight was estimated by electrophoresis and tested against vaginal pathogenic microorganisms. As described for other bacteriocins, batch fermentation profiles indicated that bacteriocin production occurs during the exponential growth phase of the lactobacilli, and declines during their stationary growth phase. The molecular weight of the bacteriocin is approximately $7.5 \mathrm{kDa}$. The bacteriocin containing protein extract was shown to inhibit the growth of Gardnerella vaginalis, Streptococcus agalactiae, Pseudomonas aeruginosa and the indicator strain Lactobacillus delbrueckii ATCC9649. We conclude that L. acidophilus KS400 produces bacteriocin with antimicrobial activity against relevant urogenital pathogens.
\end{abstract}

Keywords: Lactobacillus acidophilus KS400, Vaginal probiotics, Vaginal lactobacilli, Bacteriocins, Vaginal infections

\section{Introduction}

The term probiotic was derived from the Greek 'biotikos', meaning "for life" and refers to "live microorganisms which when administered in adequate amounts confer a health benefit on the host" (FAO 2006). In last three decades, the use of probiotics has received much attention as a treatment and prevention option for vaginal disorders (Barrons and Tassone 2008; Coudeyras et al. 2009; Homayouni et al. 2014). The equilibrium between the several microorganisms that compose the human vaginal microflora is important for the maintenance of its homeostasis, affecting directly the health status of woman (Gajer et al. 2012; Ravel et al. 2011). Among the prevalent

\footnotetext{
*Correspondence: apo@fcsaude.ubi.pt

${ }^{2}$ CICS-UBI: Health Sciences Research Centre, Covilhã, Portugal

Full list of author information is available at the end of the article
}

microorganisms, the Lactobacillus species represent at least $70 \%\left(10^{7}-10^{8} \mathrm{CFU}\right.$ (colony forming units)/g of vaginal fluid) of the bacteria identified in the reproductive system of healthy premenopausal women (Anukam et al. 2006; Ravel et al. 2011; Strus et al. 2005; Zhou et al. 2004). The most prevalent Lactobacillus spp. in the vagina are L. crispatus, L. jensenii, L. gasseri and L. iners (Pavlova et al. 2002; Vásquez et al. 2002; Zhou et al. 2010). In the vaginal epithelium, Lactobacillus induce probiosis in two stages: (1) colonizing the epithelial surface, competing for attachment sites and promote pathogen co-aggregation (competitive exclusion) (Coudeyras et al. 2009; Martín et al. 2012; Zárate and Nader-Macias 2006); and (2) producing antimicrobial metabolite substances that are able to control the remaining vaginal microflora (microbial killing, inhibition) (Heng-Yi et al. 2008; Kaewsrichan et al. 2006; Voravuthikunchai et al. 2006). Within the different 
metabolites produced by Lactobacillus, organic acids (mainly lactic acid) and hydrogen peroxide are responsible for broad-spectrum microbial inhibitory effect (O'Hanlon et al. 2013; Tomás et al. 2003). On top of this, production of more specific antimicrobial proteins (bacteriocins) have been described (Aroutcheva et al. 2001; Pingitore et al. 2009; Turovskiy et al. 2009). Bacteriocins are molecules with proteinaceous nature which have bactericidal or bacteriostatic activity against closely related species (narrow spectrum) or across genera (broad spectrum) (Cotter et al. 2005; Klaenhammer 1993). Gram-positive bacteria, especially lactic acid bacteria (lactobacilli, lactococci and pediococci), produce these antimicrobial peptides and proteins in the ribosomes, such as lactacin B from Lactobacillus acidophilus (Barefoot and Klaenhammer 1983; Muriana and Klaenhammer 1991), plantaricin 423 from Lactobacillus plantarum (Van Reenen et al. 1998), pediocin ST18 from Pediococcus pentosaceus (Todorov and Dicks 2005), nisin Q from Lactococcus lactis (Zendo et al. 2003) and several others from other bacteria (Netz et al. 2002; Srionnual et al. 2007). Due all above characteristics, Lactobacillus species have been proposed as vaginal probiotic and used for the reestablishment of the vaginal environment balance, preventing growth of pathogens in the vagina (Kaewsrichan et al. 2006; Zárate and Nader-Macias 2006). The safe use of Lactobacillus species as probiotic agents in human vagina dates back to 1915 (Newman 1915). In this in vitro study, we evaluated whether Lactobacillus acidophilus KS400 (LaKS400, Gynoflor ${ }^{\circledR}$, Medinova AG, Switzerland) is a bacteriocin producer and its antimicrobial activity.

\section{Materials and methods}

\section{Microorganism strains}

The bacterial and fungal strains used in this study, including the investigated strain ( $L a \mathrm{KS} 400$ ), the bioactivity indicator strain (Lactobacillus delbrueckii ATCC9649) and urogenital pathogens selected to assess the protein antimicrobial activity are shown in Table 1 . Bacterial and fungal strains suspended in adequate medium added with $25 \%$ of glycerol (VWR, Spain) and stored frozen at $-80{ }^{\circ} \mathrm{C}$, until used.

When gelose medium was required (for example, for the maintenance of microorganisms), bacteriological agar (VWR, Spain) was added to the liquid medium at the final concentration of $20 \mathrm{~g} / \mathrm{L}$. De Man, Rogosa and Sharpe (MRS) soft agar was prepared with $7.5 \mathrm{~g} / \mathrm{L}$ bacteriological agar.

\section{Bacteriocin detection}

LaKS400 was cultivated in $10 \mathrm{~mL}$ MRS broth (VWR, Spain) $\mathrm{pH} 6.5$ for $24 \mathrm{~h}$ at $37^{\circ} \mathrm{C}$ in the presence of $10 \%$ $\mathrm{CO}_{2}$. After incubation, the cell culture was heated at $70{ }^{\circ} \mathrm{C}$ for $30 \mathrm{~min}$ to assure inhibition of protease activity, then cooled at room temperature and centrifuged (4500 rpm for $15 \mathrm{~min}$ at $4{ }^{\circ} \mathrm{C}$ ) with a benchtop centrifuge (Heraeus megafuge $8 \mathrm{R}$ centrifuge, Thermo-fisher Scientific, EUA). In order to eliminate the antimicrobial effect of organic acids, the $\mathrm{pH}$ of the supernatants was adjusted to 6.5 with $10 \mathrm{M} \mathrm{NaOH}$ solution. The inhibitory activity from hydrogen peroxide was eliminated by the addition of $5 \mathrm{mg} / \mathrm{mL}$ catalase from bovine liver (Sigma-Aldrich, EUA) followed by filtration through a $0.2 \mu \mathrm{m}$ pore-size cellulose acetate (Fisher-Scientific, UK).

Bacteriocin detection was performed by using a modification of the antagonist well-diffusion method described

Table 1 Bacterial and fungal strains used in this study

\begin{tabular}{|c|c|c|}
\hline Microorganisms & Source & $\begin{array}{l}\text { Growth condition } \\
\text { (media, temperature } \\
\text { and atmosphere) }\end{array}$ \\
\hline Lactobacillus acidophilus KS400 & Medinova & $\mathrm{MRSB}, 37^{\circ} \mathrm{C}, 10 \% \mathrm{CO}_{2}$ \\
\hline Lactobacillus delbrueckii ATCC9649a & ATCC collection & $\mathrm{MRSB}, 37^{\circ} \mathrm{C}, 10 \% \mathrm{CO}_{2}$ \\
\hline Gardnerella vaginalis 586876 & Clinical & $\mathrm{NYCIIIB}, 37^{\circ} \mathrm{C}, 10 \% \mathrm{CO}_{2}$ \\
\hline Gardnerella vaginalis 563765 & Clinical & $\mathrm{NYCIIIB}, 37^{\circ} \mathrm{C}, 10 \% \mathrm{CO}_{2}$ \\
\hline Gardnerella vaginalis 568799 & Clinical & $\mathrm{NYCIIB}, 37^{\circ} \mathrm{C}, 10 \% \mathrm{CO}_{2}$ \\
\hline Staphylococcus aureus ATCC6538 & Collection & $\mathrm{TSB}, 37^{\circ} \mathrm{C}$, aerobic \\
\hline Streptococcus agalactiae 181324 & Clinical & $\mathrm{BHIB}, 37^{\circ} \mathrm{C}$, aerobic \\
\hline Streptococcus agalactiae 179954 & Clinical & $\mathrm{BHIB}, 37^{\circ} \mathrm{C}$, aerobic \\
\hline Pseudomonas aeruginosa ATCC15442 & Collection & $\mathrm{TSB}, 37^{\circ} \mathrm{C}$, aerobic \\
\hline Escherichia coli ATCC8739 & Collection & $\mathrm{TSB}, 37^{\circ} \mathrm{C}$, aerobic \\
\hline Candida albicans ATCC10231 & Collection & $\mathrm{BHIB}, 37^{\circ} \mathrm{C}$, aerobic \\
\hline
\end{tabular}

a Indicator microorganism 
by Tagg and McGiven (1971): briefly, $20 \mathrm{~mL}$ of MRS soft agar was inoculated with $200 \mu \mathrm{l}$ of the indicator microorganism (Lactobacillus delbrueckii ATCC9649) in an overnight culture. Wells with $4 \mathrm{~mm}$ diameter were punched in agar plates and filled with $100 \mu \mathrm{l}$ of cell-free culture supernatants. Phosphate-buffered saline (PBS) was used as negative control. The plates were maintained at room temperature for $3 \mathrm{~h}$ to allow for bacteriocin diffusion, followed by incubation at $37^{\circ} \mathrm{C}$ in the presence of $10 \% \mathrm{CO}_{2}$, during $24-48 \mathrm{~h}$. The bacteriocin activity was determined by macroscopic observation of a clear inhibition zone on the agar.

\section{Bacteriocin production}

To study the bacteriocin production kinetics, $500 \mathrm{~mL}$ of MRS broth at pH 6.5 were inoculated with LaKS400 strain $(1 \% \mathrm{v} / \mathrm{v})$ and incubated at $37{ }^{\circ} \mathrm{C}$ in the presence of gaseous nitrogen without agitation. At every hour during fermentation, both bacterial cell density and the culture medium $\mathrm{pH}$ were measured. Every $2 \mathrm{~h}$ we proceeded to the evaluation of antimicrobial activity against the indicator strain (Lactobacillus delbrueckii ATCC9649) as described above.

For bacteriocin production, a $20 \mathrm{~h}$ old culture $(10 \mathrm{~mL})$ of $L a K S 400$ was inoculated $(1 \% \mathrm{v} / \mathrm{v})$ in $1 \mathrm{~L}$ of MRS broth. Batch fermentation was performed at $37{ }^{\circ} \mathrm{C}$, without agitation, in the presence of nitrogen for $24 \mathrm{~h}$. This procedure ensures an interruption of the bacterial growth prior to the stationary phase. Thus, it is prevented that proteases released into the extracellular medium degrade the bacteriocin.

\section{Preparation of bacteriocin extracts}

Bacteriocin extracts were prepared according to the method described by Yang et al. (1992) with some modifications. Briefly, $1 \mathrm{~L}$ of culture medium from LaKS400 cells fermentation was adjusted to $\mathrm{pH} 6.5$ with $1 \mathrm{M}$ $\mathrm{NaOH}$ solution followed by stirring at room temperature for $30 \mathrm{~min}$, in order to allow the adsorption of bacteriocin to the producer cells. Then, the culture was heated at $70{ }^{\circ} \mathrm{C}$ for $30 \mathrm{~min}$. Bacterial cells were harvested by benchtop centrifuge (Heraeus megafuge 8R centrifuge, Thermo-fisher Scientific, EUA) at $4500 \mathrm{rpm}$ for $15 \mathrm{~min}$ at $4{ }^{\circ} \mathrm{C}$ and then were washed twice with $5 \mathrm{mM}$ sodium phosphate ( $\mathrm{pH}$ 6.5) and harvested by centrifugation in the same conditions. Then, bacterial cells were resuspended in $50 \mathrm{~mL}$ of $100 \mathrm{mM} \mathrm{NaCl}$ at $\mathrm{pH} 2.0$ (adjusted with $5 \%$ phosphoric acid) and mixed with a magnetic stirrer for $1 \mathrm{~h}$ at $4{ }^{\circ} \mathrm{C}$. The cell suspension was then centrifuged at $4500 \mathrm{rpm}$ for $15 \mathrm{~min}$ at $4{ }^{\circ} \mathrm{C}$ and cell-free supernatant adjusted to pH 6.5 with $1 \mathrm{M} \mathrm{NaOH}$ solution. Bacteriocin extract obtained was filtrated through a $0.2 \mu \mathrm{m}$ pore-size cellulose acetate (Fisher Scientific, UK) and the bioactivity was tested as previously described.

\section{Electrophoresis}

As 1D protein electrophoresis (separation in one dimension) allows to separate biomolecules based on their size and structure, bacteriocin extract that exhibited bioactivity against the indicator strain was subjected to an electrophoresis in Tricine-SDS-PAGE on Bio-Rad Mini Protean 3 Cell apparatus (Bio-rad, USA). 4\% polyacrylamide was used in the stacking gel and $16 \%$ polyacrylamide in the separation gel, as described by Schägger (2006). This procedure was made in duplicate. A $25 \mu \mathrm{L}$ of bacteriocin sample was mixed with $25 \mu \mathrm{L}$ of twofold concentrated buffer (Tris base $100 \mathrm{mM}$, glycine $100 \mathrm{mM}$, SDS $4 \%$, urea $8 \mathrm{M}$, bromophenol blue $0.01 \%$ ) and heated for 5 min at $100{ }^{\circ} \mathrm{C}$. NZYColour Protein Marker II (NZYTech, Portugal), was used as molecular weight marker, with sizes ranging from 11 to $245 \mathrm{kDa}$. Electrophoresis was run at constant $35 \mathrm{~mA}$ for stacking gel and $50 \mathrm{~mA}$ for resolution gel.

In order to identify the position of the active bacteriocin, one half of the gel was fixed with methanol and acetic acid and washed three times with $250 \mathrm{~mL}$ of MiliQ Water for no longer than $30 \mathrm{~min}$. The gel was then placed in a sterile petri dish and overlaid with MRS soft agar medium with 1\% Lactobacillus delbrueckii ATCC 9649. The active bacteriocin was detected by macroscopic observation of an inhibition halo, after incubating at $37^{\circ} \mathrm{C}$, during $48 \mathrm{~h}$ in the presence of $\mathrm{CO}_{2} 10 \%$. The other half of the gel was observed and photo-documented in Bio-Rad ChemiDoc MP in stain free mode. In addition, the influence of $\beta$-mercaptoethanol, on the bacteriocin antimicrobial activity was tested in order to confirm if the active protein had disulfide bridges. In fact $\beta$-mercaptoethanol is described as being responsible for the loss of the bacteriocin antimicrobial activity (Aslam et al. 2011; Deraz et al. 2007).

\section{Antimicrobial activity}

The bacteriocin antimicrobial activity was assessed following the microdilution method as described elsewhere (Rex et al. 2008; Standards 2006). Briefly, wells from a microplate were filled with $100 \mu \mathrm{L}$ of bacteriocin extract prepared as described previously and $100 \mu \mathrm{L}$ of pathogen suspension in culture medium (containing $1 \times 10^{5}$ cells assessed by optical density). Negative controls were performed corresponding to bacteriocin extract in sterile culture medium ( 2 wells for each type of culture medium used to support the pathogens growth); positive controls corresponded to $100 \mu \mathrm{L}$ of 
pathogen suspension and $100 \mu \mathrm{L}$ of PBS replacing the bacteriocin extract. The microplate was incubated at optimal growth conditions for the enrolled pathogens. After incubation, the presence or absence of pathogen growth in each well was compared to the growth obtained in the positive control. For this assay the enrolled pathogenic microorganisms were described on Table 1.

\section{Results}

\section{Bacteriocin detection}

The antimicrobial activity of the bacteriocin produced by LaKS400, obtained from the filtered culture medium after organic acids and hydrogen peroxide neutralization, showed a clear inhibition zone in agar when compared with negative control (PBS) (no inhibition observed), using Lactobacillus delbrueckii ATCC9649 as indicator organism (Fig. 1).

\section{Bacteriocin production and metabolites kinetic}

The organic acids produced by Lactobacillus (consequent to carbohydrates fermentation) induce a $\mathrm{pH}$ decrease of the medium. Batch-fermentation approach confirms a decrease in $\mathrm{pH}$ resulting from organic acid accumulation in the extracellular medium (Fig. 2, yellow line). After $36 \mathrm{~h}$ of LaKS400 fermentation the $\mathrm{pH}$ value was 4.3. In this study, the antimicrobial effect of organic acids was neutralized by the addition of a base solution, in order to eliminate its possible influence in the antimicrobial assessment of the bacteriocin. In addition, we have also considered that during batch fermentation included in our procedure, some amount of hydrogen peroxide could have been produced, thus

Fig. 1 Antimicrobial activity of Lactobacillus acidophilus KS400 bacteriocin against Lactobacillus delbrueckii ATCC9649. Culture extracts of Lactobacillus acidophilus KS400 tested by the agar well diffusion method described (Tagg and McGiven 1971). S1_culture medium from Lactobacillus acidophilus KS400 medium; PBS 1Xnegative control corresponding to $\times 1$ phosphate buffered saline
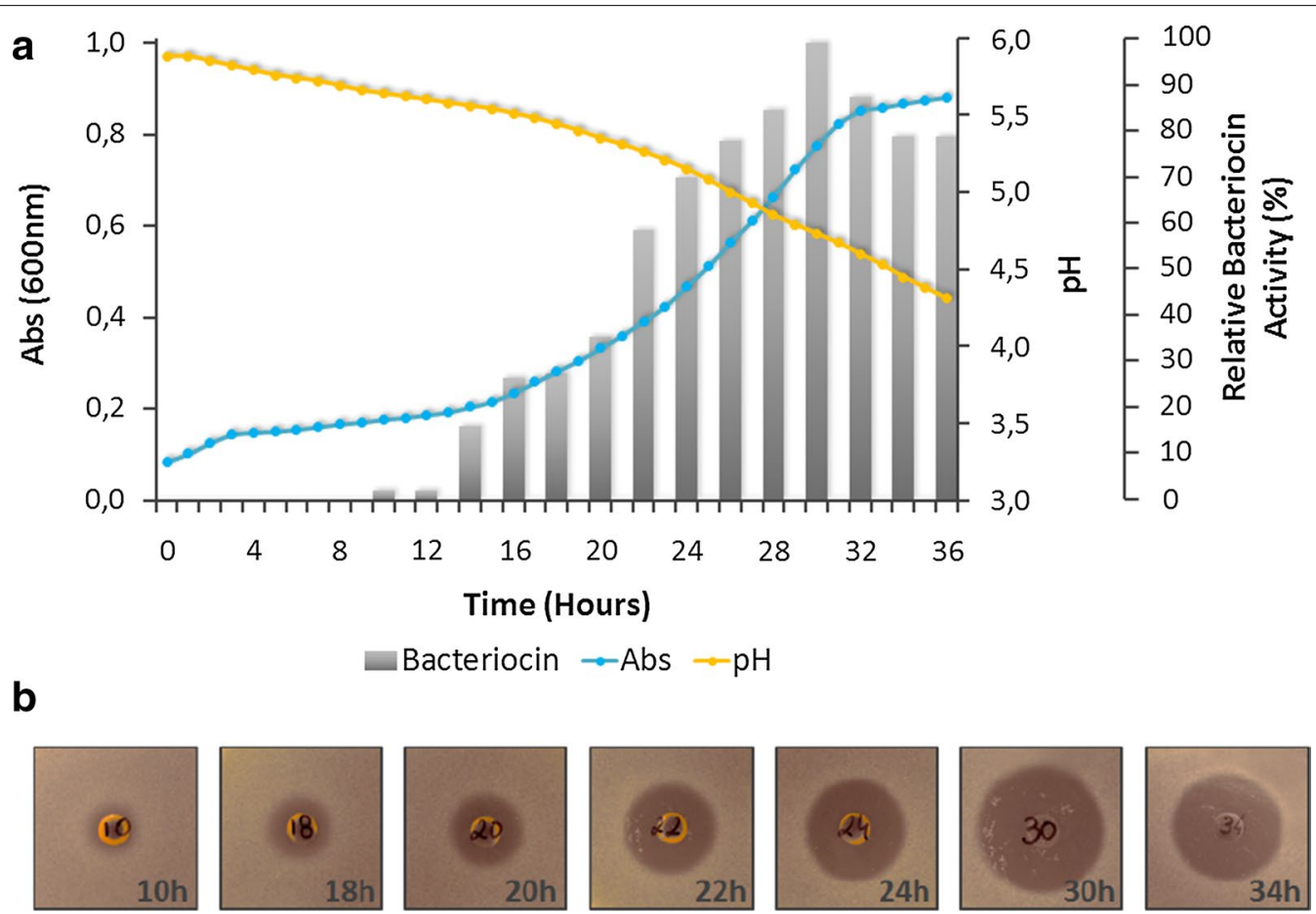

Fig. 2 a Batch fermentation of Lactobacillus acidophilus KS400 strain in MRSB with non-controlled pH (initial value of 6.5 ) at $37^{\circ} \mathrm{C}$. Left axis: absorvance (Abs) at $600 \mathrm{~nm}$; Primary right axis: $\mathrm{pH}$ values; Secondary right axis: Relative bacteriocin activity (\%); Bottom axis: Time (hours). Symbols:(•) Optical density at 600 nm;(•) Changes in pH values; (-grey bars-) Bacteriocin activity production. b Antimicrobial activity of Lactobacillus acidophilus KS400 strain during fermentation; Activity was tested against Lactobacillus delbrueckii ATCC9649 and plates were incubated at $37{ }^{\circ} \mathrm{C} ; 10 \%$ $\mathrm{CO}_{2}$ 
we proceeded to its catalysation by adding catalase to the medium after the fermentation was completed. Thus, the relative bacteriocin activity was determined in relation to the sample that showed highest bioactivity (at time $30 \mathrm{~h}$ ). The batch fermentation profiles of LaKS400 indicated that the bacteriocin production was more evident and clearly increased during the exponential growth phase, followed by a reduction during the stationary growth phase, as shown in Fig. 2a (grey bars).

After $32 \mathrm{~h}$ of fermentation a loss on the bacteriocin antimicrobial activity was observed (Fig. 2), by halo inhibition decrease.

\section{Bacteriocin molecular weight}

Proteins were separated and a bioactivity assay was carried out with an indicator strain (Lactobacillus delbrueckii ATCC9649) directly on gel electrophoresis (Fig. 3b), in order to identify the active protein. Tricine-SDS-PAGE gel extraction of proteins resulted in a single zone of growth inhibition when the gel was overlaid with the indicator strain (Fig. 3). Adding $\beta$-mercaptoethanol did not influence the bacteriocin antimicrobial activity $(+\beta$ in Fig. 3$)$.

The protein exhibiting antimicrobial activity in the electrophoresis gel corresponded to a band with an estimated molecular weight of approximately $7.5 \mathrm{kDa}$, considering that bioactivity and bacteriocin band was observed below to the $11 \mathrm{kD}$ marker protein.

\section{Bacteriocin activity against pathogenic strains}

The LaKS400 bacteriocin extract was tested against the indicator strain, pathogenic bacteria (including collection and clinical isolates) and Candida albicans ATCC10231 as shown in Table 2.

The bacteriocin extract was shown to inhibit the growth of the indicator strain Lactobacillus delbrueckii ATCC9649, Gardnerella vaginalis, Streptococcus agalactiae and Pseudomonas aeruginosa. No antimicrobial effect was observed against the enrolled strains of Escherichia coli, Staphylococcus aureus and Candida albicans.

\section{Discussion}

This study aimed to evaluate the ability of LaKS400 to produce bacteriocin with antimicrobial activity against urogenital pathogens, expressing mechanism of action that was not previously reported in other in vitro studies performed for this strain (Ünlü and Donders 2011).

The bacteriocin production and detection was performed in vitro and accompanied by the production of other bacterial metabolites (such as lactic acid and hydrogen peroxide) that were previously described for this strain. Thus, to assure that the bioactivity assessed for the protein extract was not related to these metabolites, their effect was neutralized. Thus, the experimental results suggest that a proteinaceous antimicrobial compound, bacteriocin, had been produced and secreted by LaKS400 into the extracellular culture medium. The bacteriocin production occurs during the exponential phase reaching its maximum during the stationary phase of the strain growth curve (between 24 and $30 \mathrm{~h}$ after the start

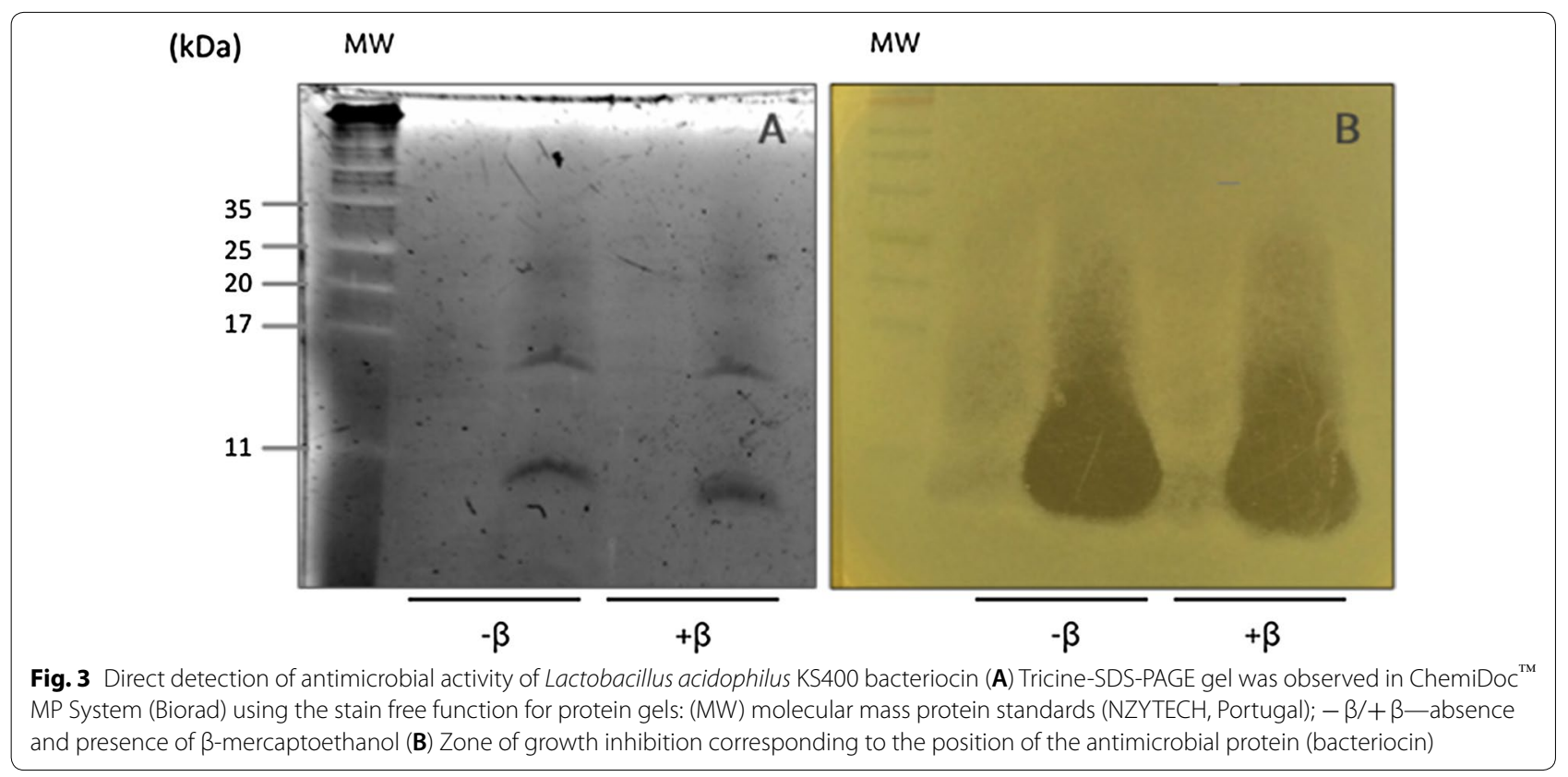


Table 2 Inhibitory spectrum of antimicrobial bacteriocin produced by Lactobacillus acidophilus KS400 against indicator strain and pathogenic microorganisms

\begin{tabular}{|c|c|c|c|}
\hline Microorganisms & Source & Growth condition & Inhibition \\
\hline Lactobacillus delbrueckii ATCC9649a & Collection & $\mathrm{MRSB}, 37^{\circ} \mathrm{C}, 10 \% \mathrm{CO}_{2}$ & + \\
\hline Gardnerella vaginalis 586876 & Clinical & $\mathrm{NYCl} \| \mathrm{BB}, 37^{\circ} \mathrm{C}, 10 \% \mathrm{CO}_{2}$ & + \\
\hline Gardnerella vaginalis 563765 & Clinical & $\mathrm{NYClIIB}, 37^{\circ} \mathrm{C}, 10 \% \mathrm{CO}_{2}$ & + \\
\hline Gardnerella vaginalis 568799 & Clinical & $\mathrm{NYCl} \| \mathrm{B}, 37^{\circ} \mathrm{C}, 10 \% \mathrm{CO}_{2}$ & + \\
\hline Staphylococcus aureus ATCC6538 & Collection & TSB, $37^{\circ} \mathrm{C}$, aerobic & - \\
\hline Streptococcus agalactiae 181324 & Clinical & $\mathrm{BHIB}, 37^{\circ} \mathrm{C}$, aerobic & + \\
\hline Streptococcus agalactiae 179954 & Clinical & $\mathrm{BHIB}, 37^{\circ} \mathrm{C}$, aerobic & + \\
\hline Pseudomonas aeruginosa ATCC 15442 & Collection & $\mathrm{TSB}, 37^{\circ} \mathrm{C}$, aerobic & + \\
\hline Escherichia coli ATCC8739 & Collection & $\mathrm{TSB}, 37^{\circ} \mathrm{C}$, aerobic & - \\
\hline Candida albicans ATCC10231 & Collection & $\mathrm{BHIB}, 37^{\circ} \mathrm{C}$, aerobic & - \\
\hline
\end{tabular}

a Indicator microorganism

of fermentation), as described for other bacteriocins (De Vuyst et al. 1996; De Vuyst and Vandamme 1992; Zamfir et al. 2000). However, after $32 \mathrm{~h}$ of fermentation a loss on the bacteriocin antimicrobial activity was observed. This change in the bioactivity can be related to protein aggregation or proteolytic degradation of the bacteriocin (Law and Kolstad 1983).

Based on the described results we conclude that LaKS400 produces a bacteriocin with an expected size of $7.5 \mathrm{kDa}$. This molecular weight is within the range of the most frequently reported bacteriocins from Lactobacillus spp. (Vuyst and Vandamme 1994). In fact, for Lactobacillus acidophilus, the size described for bacteriocins ranges from 2.5 to $100 \mathrm{kda}$ (Barefoot and Klaenhammer 1983; Muriana and Klaenhammer 1991; Zamfir et al. 1999). In addition, no decrease on antimicrobial activity was observed for bacteriocin extract in the presence of $\beta$-mercaptoethanol. This result suggests that the activity was not related to the presence of disulfide bridges. These are characteristic of class II bacteriocins, since its contains at least two cysteines in their composition that forms a bond (Ennahar et al. 2000). Disulfide bridges have been described in some Lactobacillus spp., such as L. curvatus (Tichaczek et al. 1993), L. plantarum (Ennahar et al. 1996) and L. sake (Schillinger and Lücke 1989), among others. Further studies may be carried out that include cloning, expression and isolation in vector and host microorganism in order to elucidate about its function.

In parallel, we conducted antimicrobial tests to access the bacteriocin extract bioactivity against several urogenital pathogens. Bacteriocin extract was shown to inhibit the growth of the indicator strain, Gram-positive (Gardnerella vaginalis and Streptococcus agalactiae) and Gram-negative bacteria Pseudomonas aeruginosa. However, no antimicrobial effect was observed against the enrolled strains of Escherichia coli, Staphylococcus aureus and Candida albicans. This finding was not unexpected as bacteriocins act mainly against the closely related species, while against fungi, the lactobacilli activity, if at all present, is probably related with different antimicrobial effects, like competition for adhesion sites. Similar results were observed in another published study (Mitra et al. 2005), while it has been described that bacteriocins produced by Lactic acid bacteria (including Lactobacillus) are primarily active against Gram-positive bacteria (Heng et al. 2007; Jack et al. 1995). Moreover, several studies have been published regarding bacteriocins produced by Lactobacillus acidophilus. For example, Lactobacillus acidophilus DSM20079 produced an antimicrobial bacteriocin (acidocin D20079) with approximately $6.6 \mathrm{kDa}$ that had an inhibitory activity against Lactobacillus genus, including Lactobacillus delbrueckii subsp. lactis DSM20076, Lactobacillus bulgaricus DSM20080 and Lactobacillus sakei NCDO2714, but no evident activity was observed against other pathogens (Deraz et al. 2005). Furthermore, it has been also described by other authors that active bacteriocins produced by Lactobacillus acidophilus, are small peptides with different physicochemical properties. In fact, for Lactobacillus acidophilus JCM1132 a heat-stable two-component bacteriocin (J1132) exhibiting a narrow inhibitory activity against non-pathogenic strains has been described (Tahara et al. 1996), and a bacteriocin with $3.1 \mathrm{kDa}$ active against pathogenic strains was identified for Lactobacillus acidophilus ATCC4356 (Han et al. 2002).

These results corroborate the LaKS400 probiotic efficacy in vaginal application or its use in other pathologies. In fact, this study reports for the first time a new bacteriocin produced by LaKS400, with an expected size of $7.5 \mathrm{kDa}$ and antimicrobial activity against vaginal pathogen microorganisms, specifically Gardnerella vaginalis 
and Streptococcus agalactiae, two most relevant pathogens related to vaginal infections. These results corroborate a new mechanism of action for this probiotic strain and support its use in clinical practice for the treatment and prevention of vaginal infections. Further studies may be carried out to improve bacteriocin production, isolation, purification and elucidate about its possible mechanism of action.

\section{Abbreviations \\ LaKS400: Lactobacillus acidophilus KS400; MRS: De Man, Rogosa and Sharpe; PBS: phosphate-buffered saline.}

\section{Authors' contributions}

CG performed the laboratory work and wrote the first version of the manuscript; RPO contributed with her expertise in some laboratory tasks and critical review of the manuscript; JAQ and CT contributed with their expertise in chromatography techniques both for study plan design, results discussion and critical review of the final manuscript; GGD, JMO and APO proposed the study plan, with the overall approach, contributed to critical discussion of the results and reviewed the manuscript. All authors read and approved the final manuscript.

\section{Author details}

${ }^{1}$ Labfit-HPRD: Health Products Research and Development, Lda, Covilhã, Portugal. ${ }^{2}$ CICS-UBI: Health Sciences Research Centre, Covilhã, Portugal. ${ }^{3}$ Antwerp University Hospital, Antwerp, Belgium. ${ }^{4}$ Femicare vzw clinincal Research for Women, Tienen, Belgium. ${ }^{5}$ Child and Women's Health Department, Centro Hospitalar Cova da Beira EPE, Covilhã, Portugal.

\section{Competing interests}

The authors declare that they have no competing interests.

\section{Consent for publication}

Not applicable.

\section{Ethics approval and consent to participate}

This article does not contain any studies with human participants or animals performed by any of the authors.

\section{Funding}

This work was supported by FEDER funds through the POCI-COMPETE 2020-Operational Programme Competitiveness and Internationalisation in Axis I-Strengthening research, technological development and innovation (Project POCI-01-0145-FEDER-007491) and National Funds by FCT_-Foundation for Science and Technology, Portugal (Project UID/Multi/00709/2013). Part of human resources, consumables and reagents as well as publication charges, were funded by Medinova but all the results achieved are reported in this document (including the negative ones) and no member of Medinova has interfered in the experiments design, results discussion or final manuscript format.

\section{Publisher's Note}

Springer Nature remains neutral with regard to jurisdictional claims in published maps and institutional affiliations.

Received: 26 March 2018 Accepted: 18 September 2018

Published online: 27 September 2018

\section{References}

Anukam KC, Osazuwa EO, Ahonkhai I, Reid G (2006) Lactobacillus vaginal microbiota of women attending a reproductive health care service in Benin city, Nigeria. Sex Transm Dis 33(1):59-62
Aroutcheva AA, Simoes JA, Faro S (2001) Antimicrobial protein produced by vaginal Lactobacillus acidophilus that inhibits Gardnerella vaginalis. Infect Dis Obstet Gynecol 9(1):33-39

Aslam M, Shahid M, Rehman FU, Naveed NH, Batool Al, Sharif S, Asia A (2011) Purification and characterization of bacteriocin isolated from Streptococcus thermophilus. Afr J Microbiol Res. 5(18):2642-2648

Barefoot SF, Klaenhammer TR (1983) Detection and activity of lactacin B, a bacteriocin produced by Lactobacillus acidophilus. Appl Environ Microbiol 45(6):1808-1815

Barrons R, Tassone D (2008) Use of Lactobacillus probiotics for bacterial genitourinary infections in women: a review. Clin Ther 30(3):453-468

Cotter PD, Hill C, Ross RP (2005) Bacteriocins: developing innate immunity for food. Nat Rev Microbiol 3(10):777-788

Coudeyras S, Jugie G, Vermerie M, Forestier C (2009) Adhesion of human probiotic Lactobacillus rhamnosus to cervical and vaginal cells and interaction with vaginosis-associated pathogens. Infect Dis Obstet Gynecol 2008:1

De Vuyst L, Vandamme EJ (1992) Influence of the carbon source on nisin production in Lactococcus lactis subsp. lactis batch fermentations. Microbiology 138(3):571-578

de Vuyst L, Vandamme EJ (1994) Bacteriocins of lactic acid bacteria: microbiology, genetics and applications. Blackie Academic \& Professional, Boca Raton

De Vuyst L, Callewaert R, Crabbe K (1996) Primary metabolite kinetics of bacteriocin biosynthesis by Lactobacillus amylovorus and evidence for stimulation of bacteriocin production under unfavourable growth conditions. Microbiology 142(4):817-827

Deraz SF, Karlsson EN, Hedström M, Andersson MM, Mattiasson B (2005) Purification and characterisation of acidocin D20079, a bacteriocin produced by Lactobacillus acidophilus DSM 20079. J Biotechnol 117(4):343-354

Deraz SF, Hedström M, Karlsson EN, Linse S, Khalil AA, Mattiasson B (2007) Production and physicochemical characterization of acidocin D20079, a bacteriocin produced by Lactobacillus acidophilus DSM 20079. World J Microbiol Biotechnol 23(7):911-921

Ennahar S, Aoude-Werner D, Sorokine O, Van Dorsselaer A, Bringel F, Hubert JC, Hasselmann C (1996) Production of pediocin AcH by LactobacilIus plantarum WHE 92 isolated from cheese. Appl Environ Microbiol 62(12):4381-4387

Ennahar S, Sashihara T, Sonomoto K, Ishizaki A (2000) Class lla bacteriocins: biosynthesis, structure and activity. FEMS Microbiol Rev. https://doi. org/10.1016/S0168-6445(99)00031-5

FAO (2006) Probiotics in food: health and nutritional properties and guidelines for evaluation. FAO, Rome

Gajer P, Brotman RM, Bai G, Sakamoto J, Schütte UME, Zhong X, Koenig SSK, Fu L, Ma ZS, Zhou X (2012) Temporal dynamics of the human vaginal microbiota. Sci Transl Med 4(132):132ra52

Han KS, Imm JY, Oh S, Jeon WM, Kim SH (2002) Bacteriocin produced by Lactobacillus acidophilus ATCC 4356. Food Sci Biotechnol. 11(5):531-536

Heng NCK, Wescombe PA, Burton JP, Jack RW, Tagg JR (2007) The diversity of bacteriocins in Gram-positive bacteria: bacteriocins. Springer, Berlin, pp 45-92

Heng-Yi XU, Wan-Hong T, Cui-Xiang WAN, Li-Jun JIA, Lan-Yin W, Jing Y, ChunMei LIU, Ming Z, Hua WEI (2008) Antagonistic potential against pathogenic microorganisms and hydrogen peroxide production of indigenous lactobacilli isolated from vagina of Chinese pregnant women. Biomed Environ Sci 21(5):365-371

Homayouni A, Bastani P, Ziyadi S, Ghalibaf M, Mortazavian AM, Mortazavian AM, Mehrabany EV (2014) Effects of probiotics on the recurrence of bacterial vaginosis: a review. J Low Genit Tract Dis. 18(1):79-86

Jack RW, Tagg JR, Ray B (1995) Bacteriocins of gram-positive bacteria. Microbiol Rev 59(2):171-200

Kaewsrichan J, Peeyananjarassri K, Kongprasertkit J (2006) Selection and identification of anaerobic lactobacilli producing inhibitory compounds against vaginal pathogens. FEMS Immunol Med Microbiol 48(1):75-83

Klaenhammer TR (1993) Genetics of bacteriocins produced by lactic acid bacteria. FEMS Microbiol Rev 12(1-3):39-85

Law BA, Kolstad J (1983) Proteolytic systems in lactic acid bacteria. Antonie Van Leeuwenhoek 49(3):225-245

Martín R, Sánchez B, Suárez JE, Urdaci MC (2012) Characterization of the adherence properties of human Lactobacilli strains to be used as vaginal probiotics. FEMS Microbiol Lett 328(2):166-173 
Mitra S, Chakrabartty PK, Biswas SR (2005) Production and characterization of nisin-like peptide produced by a strain of Lactococcus lactis isolated from fermented milk. Curr Microbiol 51(3):183-187

Muriana PM, Klaenhammer TR (1991) Purification and partial characterization of lactacin F, a bacteriocin produced by Lactobacillus acidophilus 11088 . Appl Environ Microbiol 57(1):114-121

Netz DJ, Pohl R, Beck-Sickinger AG, Selmer T, Pierik AJ, de Freire Bastos MD, Sahl HG (2002) Biochemical characterisation and genetic analysis of aureocin A53, a new, atypical bacteriocin from Staphylococcus aureus. J Mol Biol 319(3):745-756

Newman D (1915) The treatment of cystitis by intravesical injections of lactic Bacillus cultures. Lancet 186(4798):330-332

O'Hanlon DE, Moench TR, Cone RA (2013) Vaginal pH and microbicidal lactic acid when lactobacilli dominate the microbiota. PLoS ONE 8(11):e80074

Pavlova SI, Kilic AO, Kilic SS, So J, Nader-Macias ME, Simoes JA, Tao L (2002) Genetic diversity of vaginal lactobacilli from women in different countries based on 16S rRNA gene sequences. J Appl Microbiol 92(3):451-459

Pingitore EV, Hébert EM, Nader-Macías ME, Sesma F (2009) Characterization of salivaricin CRL 1328, a two-peptide bacteriocin produced by LactobacilIus salivarius CRL 1328 isolated from the human vagina. Res Microbiol 160(6):401-408

Ravel J, Gajer P, Abdo Z, Schneider GM, Koenig SSK, McCulle SL, Karlebach S, Gorle R, Russell J, Tacket CO, Brotman RM, Davis CC, Ault K, Peralta L, Forney $L J$ (2011) Vaginal microbiome of reproductive-age women. Proc Natl Acad Sci 108(Supplement 1):4680-4687

Rex JH, Alexander BD, Andes D, Arthington-Skaggs B, Brown SD, Chaturveli V, Espinel-Ingroff A, Ghannoum MA, Knapp CC, Motyl MR. Reference method for broth dilution antifungal susceptibility testing of filamentous fungi: approved standard. 2008

Schägger H (2006) Tricine-SDS-PAGE. Nat Protoc 1:16-22

Schillinger U, Lücke FK (1989) Antibacterial activity of Lactobacillus sake isolated from meat. Appl Environ Microbiol 55(8):1901-1906. https://doi. org/10.1016/S0168-1605(03)00051-5

Srionnual S, Yanagida F, Lin L-H, Hsiao K-N, Chen Y (2007) Weissellicin 110, a newly discovered bacteriocin from Weissella cibaria 110, isolated from plaa-som, a fermented fish product from Thailand. Appl Environ Microbiol 73(7):2247-2250

Standards NC for CL. Methods for dilution antimicrobial susceptibility tests for bacteria that grow aerobically: approved standard. National Committee for Clinical Laboratory Standards; 2006

Strus M, Kucharska A, Kukla G, Brzychczy-Włoch M, Maresz K, Heczko PB (2005) The in vitro activity of vaginal Lactobacillus with probiotic properties against Candida. Infect Dis Obstet Gynecol 13(2):69-75

Tagg J, McGiven AR (1971) Assay system for bacteriocins. Appl Microbiol 21(5):943

Tahara T, Oshimura M, Umezawa C, Kanatani K (1996) Isolation, partial characterization, and mode of action of Acidocin J1132, a two-component bacteriocin produced by Lactobacillus acidophilus JCM 1132. Appl Environ Microbiol 62(3):892-897
Tichaczek PS, Vogel RF, Hammes WP (1993) Cloning and sequencing of curA encoding curvacin $\mathrm{A}$, the bacteriocin produced by Lactobacillus curvatus LTH1174. Arch Microbiol 160(4):279-283

Todorov SD, Dicks LMT (2005) Pediocin ST18, an anti-listerial bacteriocin produced by Pediococcus pentosaceus ST18 isolated from boza, a traditional cereal beverage from Bulgaria. Process Biochem 40(1):365-370

Tomás MSJ, Ocaña VS, Wiese B, Nader-Macías ME (2003) Growth and lactic acid production by vaginal Lactobacillus acidophilus CRL 1259, and inhibition of uropathogenic Escherichia coli. J Med Microbiol 52(12):1117-1124

Turovskiy Y, Ludescher RD, Aroutcheva AA, Faro S, Chikindas ML (2009) Lactocin 160, a bacteriocin produced by vaginal Lactobacillus rhamnosus, targets cytoplasmic membranes of the vaginal pathogen, Gardnerella vaginalis. Probiotics Antimicrob Proteins 1(1):67-74

Ünlü C, Donders G (2011) Use of lactobacilli and estriol combination in the treatment of disturbed vaginal ecosystem: a review. J Turkish Ger Gynecol Assoc 12(4):239

Van Reenen CA, Dicks LMT, Chikindas ML (1998) Isolation, purification and partial characterization of plantaricin 423, a bacteriocin produced by Lactobacillus plantarum. J Appl Microbiol 84(6):1131-1137

Vásquez A, Jakobsson T, Ahrné S, Forsum U, Molin G (2002) Vaginal LactobacilIus flora of healthy Swedish women. J Clin Microbiol 40(8):2746-2749

Voravuthikunchai SP, Bilasoi S, Supamala O (2006) Antagonistic activity against pathogenic bacteria by human vaginal lactobacilli. Anaerobe 12(5):221-226

Yang R, Johnson MC, Ray B (1992) Novel method to extract large amounts of bacteriocins from lactic acid bacteria. Appl Environ Microbiol 58(10):3355-3359

Zamfir M, Callewaert R, Cornea PC, Savu L, Vatafu I, De Vuyst L (1999) Purification and characterization of a bacteriocin produced by Lactobacillus acidophilus IBB 801. J Appl Microbiol 87(6):923-931. https://doi.org/10.10 46/j.1365-2672.1999.00950.x

Zamfir M, Callewaert R, Cornea PC, De Vuyst L (2000) Production kinetics of acidophilin 801, a bacteriocin produced by Lactobacillus acidophilus IBB 801. FEMS Microbiol Lett 190(2):305-308

Zárate G, Nader-Macias ME (2006) Influence of probiotic vaginal lactobacilli on in vitro adhesion of urogenital pathogens to vaginal epithelial cells. Lett Appl Microbiol 43(2):174-180

Zendo T, Fukao M, Ueda K, Higuchi T, Nakayama J, Sonomoto K (2003) Identification of the lantibiotic nisin Q, a new natural nisin variant produced by Lactococcus lactis 61-14 isolated from a river in Japan. Biosci Biotechnol Biochem 67(7):1616-1619

Zhou X, Bent SJ, Schneider MG, Davis CC, Islam MR, Forney LJ (2004) Characterization of vaginal microbial communities in adult healthy women using cultivation-independent methods. Microbiology 150(8):2565-2573

Zhou X, Hansmann MA, Davis CC, Suzuki H, Brown CJ, Schütte U, Pierson JD, Forney $L J$ (2010) The vaginal bacterial communities of Japanese women resemble those of women in other racial groups. FEMS Immunol Med Microbiol 58(2):169-181

\section{Submit your manuscript to a SpringerOpen ${ }^{\circ}$ journal and benefit from:}

- Convenient online submission

- Rigorous peer review

- Open access: articles freely available online

- High visibility within the field

Retaining the copyright to your article

Submit your next manuscript at springeropen.com 